\title{
The Castle: The panoptical surveillance
}

\author{
Afrouz Yari ${ }^{1, ~ *, ~ S h a h r a m ~ A f r o u g h e h ~}{ }^{2}$ \\ ${ }^{1}$ M.A. English Literature, Islamic Azad University, Boroujerd Branch, Iran \\ ${ }^{2}$ Assistant Professor of English Literature Islamic Azad University, Boroujerd Branch, Iran
}

\section{Email address:}

yariafrouz@yahoo.com (A. Yari), shahram_afrougheh@yahoo.com (S. Afrougheh)

\section{To cite this article:}

Afrouz Yari, Shahram Afrougheh. The Castle: The Panoptical Surveillance. International Journal of Literature and Arts. Vol. 1, No. 3, 2013, pp. 55-58. doi: 10.11648/j.ijla.20130103.16

\begin{abstract}
This article aims to explore the issue of Franz Kafka's The Castle (1922) throughout the idea of Foucauldian Panopticon, which portrays a world seemingly controlled by whimsical leaders and absurd rules. This implication is a poached through the figure of the power. It is believed that Franz Kafka's novel is viewed as an original reflection on the use and abuse of power and loss of personal rights. Franz Kafka's novel suggests different looking toward power both panoptical system as a tyrant and also the Foucauldian one. The article notes that the idea of power, punishment, surveillance and panopticon presented in the novel reinforces the tyrant's sovereign power.
\end{abstract}

Keywords: Power, Panopticon, Punishment, Sovereign Power, Surveillance

\section{Introduction}

What is Panopticon? Jeremy Bentham expounded his theories for the construction of an ideal prison system the Panopticon following a precise architectural model. Bentham envisioned the Panopticon as consisting of a central watchtower surrounded by a circular row of cells permanently exposed to the unseen Inspector in his lodge. This prison would operate on the assumption that fear of being watched would lead the inmates not only to incorporate the rules but to regulate their own behavior as well. Foucault describes the implication of panopticon in his Discipline \& Punish: the Birth of the Prison (1975) as so:

Hence, the major effect of the Panopticon: to induce in the inmate a state of conscious and permanent visiblyity that assures the automatic functioning of power. So to arrange things that the surveillance is permanent in its effects, even if it is discontinuous in its action; that the perfection of power should tend to render its actual exercise unnecessary;[...] In view of this, Bentham laid down the principle that power should be visible and unverifiable. Visible: the inmate will constantly have before his eyes the tall outline of the central tower from which he is spied upon. Unverifiable: the inmate must never know whether he is being looked at any one moment; but he must be sure that he may always be so. In order to make the presence or absence of the inspector unverifiable, so that the prisoners, in their cells, cannot even see a shadow, Bentham envisaged. (Foucault: 195-228)
Kafka's The Castle portrays a world seemingly controlled by whimsical leaders and absurd rules. As K., land-surveyor and unwelcome guest in the village near the Castle, endeavors to reach his goals the Castle itself and the elusive Director Klamm questions arise regarding the ultimate source of power, the means of rule-enforcement, and the terms of the relationship between villagers and officials in the prison-like world created by Kafka. Regardless of who or what is in control of the Castle, of the village, and of K.'s actions, the power structures are kept in place by the pervasive fear of a ubiquitous bureaucratic system and by the threat of a punishment that is seldom actually administered or experienced. I maintain that Kafka's Castle operates on the basis of panoptic principles, relying on an authoritarian regime and permanent surveillance for the sake of individual discipline and social stability. Tracing the numerous parallels between the Castle and Bentham's Panopticon serves a twofold purpose. On the one hand, it reveals the organizing principles beneath the apparently haphazard and absurd structure of the Castle; on the other hand, it uncovers the contradictions and limitations intrinsic to the Benthamite carceral project. The present study will focus on an example of sovereign power and surveillance benefited from disciplinary one in order to reinforce the sovereignty. 


\section{The Discourse of Panoptical' System and Surveillance in the Castle}

The Panopticon was a metaphor that allowed Foucault to explore the relationship between the Systems of social control and people in a disciplinary situation and, the power/knowledge concept. In his view, power and knowledge comes from observing others. It marked the transition to a disciplinary power, with every movement supervised and all events recorded. The result of this surveillance is acceptance of regulations and docility - a normalization of sorts, stemming from the threat of discipline. Suitable behaviour is achieved not through total surveillance, but by panoptic discipline and inducing a population to conform by the internalization of this reality. The discussion of Panopticism, so often presented as the ultimate Foucauldian set piece, is predictably a more complicated and nuanced tale than many literal and even historical readings would seem to suggest. The novel begins at its end with the apparent death of the protagonist. The Castle represents both a physical and symbolic structure; its physical presence corresponds to a psychic state determined by the symbolic value of the Castle-as-Panopticon. Unlike the Inspector's lodge in Bentham's scheme, which is permanently visible, the Castle seems to dissolve, and $\mathrm{K}$. feels that "the longer he looked, the less he could make out, and the deeper everything sank into the twilight" (Pease-Watkin 99). Even though the Castle disappears from K.'s range of vision, its hidden presence still exerts a powerful influence on his actions. That the Castle is felt rather than seen and that it shifts from a solid structure into a jumble of buildings serve as indications of its illusory nature. These attributes further support the notion that the effectiveness of the power held by the Castle and by the Panopticon does not necessitate their physical presence but depends on their ultimate psychic effects on the observers. The crucial factor in panoptic surveillance and in the workings of the panoptic Castle does not lie in the intervention of the officials but in the operation of the gaze, that is, the ability of the Inspector-Director to see in all directions at all times. James Hurley argues, "The omnipresence of the panoptic eye ensures that each subject will always be on view, on display" (ibid 77).

K.'s remarks on the panopticism of the Castle resonate with the qualities of Bentham's prison. As he stares at the Castle, he has a strong intuition:

"as if he were watching someone who sat there calmly, gazing into space, not lost in thought and therefore cut off from everything, but free and untroubled; as if he were alone, unobserved; and yet it could not have escaped him that someone was observing him" (Kafka 98-99).

The existence of an all-seeing observer, presumably Klamm, foregrounds the radical need for the internalization of rules and self-vigilance. In this regard, Jeffrey Reiman claims:

"The very fact of general visibility_being seeable more than being seen-will be enough to produce effective social control. Indeed, awareness of being visible makes people the agents of their own subjection" (Reiman 160).

The constant surveillance of individual movements indicates that the system makes no allowances for intimacy or privacy. On the night K. meets Frieda at the Gentlemen's Inn, his self-proclaimed:

"Assistants" confess to having spent the whole night in the taproom while K. and Frieda were "frolicking" and lying on the filthy floor. This zealous vigilance of the assistants recurs in all the intimate moments shared by K. and Frieda. At some point, K. even regrets that "[h]e would have liked to have a confidential conversation with Frieda, but the assistants [.. .] prevented this with their intrusive presence" (Kafka 44).

After the brief interlude that follows their love-making at the Bridge Inn, K. notices, once more, the:

"Intrusive presence" of his assistants and of the landlady in the room, in an incident at the school that verges on absurdity, K. wakes up to find one of his assistants - instead of Frieda-lying by his side on the makeshift bed. These frequent invasions of privacy confirm the loss of personal rights and of selfhood in the pseudo-carceral world of the village. 8 Privacy, defined as "the condition in which other people are deprived of access to either some information about you or some experience of you" (Reiman 162).

Above quoted paragraph, it cannot exist in the panoptic Castle, for it could promote a sense of freedom opposed, in principle, to the structures of absolute power. The world of the Castle affords no room for the development of emotional ties in the form of companionship or friendship, especially because they disrupt the established order. For this reason, the affair between $\mathrm{K}$. and Frieda eventually becomes a mockery of love, as they both strive to reach their individual goals. While Frieda longs to leave, "go somewhere else, to southern France, or to Spain” (Kafka 136), K. single-mindedly attempts to stay and gain access to the Castle by any available means. In his interaction with the villagers, K. must confront not only their hostility but also their unquestioning obeisance to the castle rules: no unauthorized persons can stay in the village without a permit; no one can get a permit; no one can see Klamm's face. 10 no one who is not a gentleman can stay at the Gentlemen's Inn; no one who is not an official, servant, or messenger can reach the Castle.

At first glance, the ultimate source of power could be located within the Castle, more specifically in the figure of Director Klamm. The boundaries between Castle and village, however, are 10In an extreme instance of not clearly demarcated, and since the village is "Castle property," it stands as a constituent part of its structure of power as well. On the other hand, the effectiveness of a system in which punishment is mostly self-inflicted and socially enforced becomes evident during the events leading to, and following, the downfall of the Barnabas family. After Amalia's defiance of a Castle official, her whole family falls into disrepute simply by their association with her.

The Barnabas family undergoes public disgrace so that 
others may learn the dire consequences of transgression. Thus their punishment consists in the dual burden of stigmatization and ostracism in their community.

As in Foucault's ideal, "punishment is first and foremost spectacle: it is insofar as punishment is not intended for the punished individual, but for all others, that the execution of the punishment is a spectacle" (Bozovic 4). Therefore, Barnabas families expose the intrinsic perverseness of a system that aims to dehumanize its subjects. Because the Castle works in accordance with panoptic principles, its methods and their effects can be perceived primarily at the level of the mind and the imaginary. With the construction of the Panopticon, Bentham sought "a mode of obtaining power of mind over mind in a quantity hitherto without example" (Bentham 31). Being surrounded by a community in which they had formerly enjoyed a position of pre-eminence, the Barnabas family find themselves subjected to social isolation and to the enduring contempt of their neighbors.

The separation of the Castle as Panopticon from the village helps articulate two interrelated spaces physical and mental each reinforcing the other. The Castle occupies a central position in relation to the village, not because it lies at its very geographical center, but because of its location at a vantage point from which control and authority can be established. The spatial distance between the two spaces defines the hierarchical division between the gentle men and their social inferiors, and it incapacitates the villagers, preventing them from reaching the Castle. As K. sets off to reach the castle, he notes:

So he walked on, but it was a long way. For he was in the main street of the village, and it did not lead to Castle Mount but merely passed close to it before turning aside, as if on purpose, and although it moved no further away from the castle, it came no closer either. K. kept thinking that the road must finally bring him to the castle, and, if only because of that expectation, he went on. Because of his weariness he naturally shrank from leaving the road, and he was surprised by the extent of the village, which seemed as if it would never end, with more and more little houses, their window-panes covered by frost-flowers, and with the snow and the absence of any human beings - so at last he tore himself away from the road on which he had persisted and struck out down a narrow alley where the snow lay even deeper. Pulling his feet out of it as they kept sinking in again was hard work. He broke out in a sweat, and suddenly he stopped and could go no further. (TC 13)

K's observation focuses directly on structural elements in the design of the Castle that make it inaccessible to any but authorized persons. His description of its exterior, particularly of the tower, also presents striking similarities to Bentham's Panopticon:

The tower up here the only visible one now turned out to belong to a dwelling, perhaps the main part of the castle. It was a simple, round building, partly covered with ivy, and it had small windows, now shining in the sun there was something crazed about the sight and was built into the shape of a balcony at the top, with insecure, irregular battlements, crumbling as if drawn by an anxious or careless child as they stood out, zigzag fashion, against the blue sky. It was as if some melancholy inhabitant of the place, who should really have stayed locked up in the most remote room in the house, had broken through the roof and was standing erect to show himself to the world. (TC 11)

In fact, as Foucault modeled his inspection tower after a church, the sight of the castle tower brings to K.'s mind recollections of the church in his hometown. These considerations of shape and structure, nonetheless, take a secondary place in relation to the symbolic function of the building. K.'s remarks on the panopticism of the castle resonate with the qualities of Foucault's prison. As he stares at the castle, he has a strong intuition:

Altogether the castle, as seen in the distance, lived up to K.'s expectations. It was neither an old knightly castle from the days of chivalry, nor a showy new structure, but an extensive complex of buildings, a few of them with two storeys, but many of them lower and crowded close together. If you hadn't known it was a castle you might have taken it for a small town. K. saw only a single tower, and could not make out whether it was a dwelling or belonged to a church. (TC 11)

As it was seen in Kafka's novel, on the hand, the existence of an all-seeing observer, presumably Klamm, foregrounds the radical need for the internalization of rules and self-vigilance. Therefore, the very fact of general visibility being seen able more than being seen will be enough to produce effective social control. Indeed, awareness of being visible makes people the agents of their own subjection. The power of the gaze, which in the Panopticon is concentrated in the figure of the Inspector, becomes dispersed in the Castle. In this respect, Hurley speaks of a visual architecture that permits the symbolic order ideology to deploy its authoritative gaze not merely omits subjects, but through them, each subject's gaze positioning his neighbor even as that neighbor's gaze positions him:

It was late evening when $\mathrm{K}$. arrived. The village lay deep in snow. There was nothing to be seen of Castle Mount, for mist and darkness surrounded it, and not the faintest glimmer of light showed where the great castle lay. K. stood on the wooden bridge leading from the road to the village for a long time, looking up at what seemed to be a void. (TC 5)

K. and Frieda are never entirely free from their observation, and, in this way, Bentham's symbolic configuration of the gaze turns into a reality of bodies gazing and being gazed at in the novel. Owing to the dispersal of the gaze, the assistants act as stand-ins for Klamm at those moments when direct viewing is made impossible by physical barriers. Whereas the gaze operates mostly, but not exclusively, on the level of the imaginary, an additional element the voice functions at the physical level:

A humming, such as $\mathrm{K}$. had never before heard on the telephone, emerged from the receiver. It was as if the 
murmur of countless childish voices - not that it was really a murmur, it was more like the singing of voices, very far away - as if that sound were forming, unlikely as that might be, into a single high, strong voice, striking the ear as if trying to penetrate further than into the mere human sense of hearing. K. heard it and said nothing; he had propped his left arm on the telephone stand, and listened like that. (TC 21)

There is no separate telephone connection to the Castle and no switchboard to forward their calls, and that all the telephones in the lowest-level departments ring or all would ring if the ringing mechanism on nearly all of them were not disconnected. Only in such exceptional circumstances as when an overtired official needs some diversion does the caller receive an answer from somebody. Because the person who picks up the phone on the receiving end may not be the one for whom the call was intended, the speaker can never ascertain the real identity of the person who answers the call. The voice, then, becomes a disembodied phenomenon in an impersonal mechanism of power. The use of the voice as well as of the gaze equates anonymity and invisibility with the exercise of power and emphasizes the type of human interactions favored by the authoritarian regime of the Castle as Panopticon. The workings of the gaze and the constant surveillance of individual movements indicate that the system makes no allowances for intimacy or privacy.

The world of the Castle affords no room for the development of emotional ties in the form of companionship or friendship, especially because they disrupt the established order. For this reason, the affair between K. and Frieda eventually becomes a mockery of love, as they both strive to reach their individual goals. While Frieda says:

I won't endure this life here anymore. If you want to keep me we must go away, emigrate, and go anywhere, to the south of France, to Spain.' 'I can't emigrate,' said K. 'I came to this place meaning to stay here, and stay I will.' And in a spirit of contradiction which he didn't even try to explain he added, as if to himself: 'What could have lured me to this desolate part of the country but a longing to stay here?' Then he added: 'But you must want to stay here too; it's your own country, after all. (TC 121-22)

$\mathrm{K}$. single-mindedly attempts to stay and gain access to the Castle by any available means. When they fail to reconcile their differing aspirations, their relationship falls apart. At the same time, their romantic liaison turns into a disturbance, that is, a challenge to the status quo that characterizes the rule of the Castle. The authoritative characters of the castle are ambiguous in order to hide their real nature from the public. As Foucault argued, the major effect of the Panopticon was "to induce in the inmate a state of conscious and permanent visibility that assures the automatic functioning of power" (1977:201).

According to, Kafka and Foucault' view we explain how the mechanisms of authority, power, surveillance, and control at work in the Castle came to bear a strong resemblance to those of the Panopticon. This, of course, does not mean Kafka deliberately intended The Castle as a critique of Foucault's penitentiary, but the Panopticon obviously suited him as a model in his portrayal of dehumanization, bureaucratization, and authoritarianism in our world. Thus their punishment consists in the dual burden of stigmatization and ostracism in their community.

\section{Conclusion}

Despite the pointless growth of Castle in this paper, the laws and the power of the gaze remain intact, as is evident from the manner in which the villagers conduct their affairs and regulate themselves in accordance with Castle rules. Therefore, K.'s experiences attest to the effectiveness of the panoptic gaze in bringing about a depersonalized society as well as to the failure of an impersonal structure of surveillance and control whose cruelty and perverseness reside in the dehumanization of Castle officials and villagers alike. Foucault did not conceive of social control for its own sake; docility and utility were inextricably linked, in such a manner that individual energy could be channeled for productive purposes.

\section{References}

[1] Bentham, Jeremy. "Panopticon; or the Inspection House." New York: Verso, 1995.

[2] Foucault, Michel. Discipline and Punishment: The Birth of the Prison. London: Penguin, 1975.

[3] Foucault, Michel. Power/Knowledge, Selected Interviews \& Other Writings. Ed. Colin Gordon, New York, the Harvester Press, 1977.

[4] Reiman, Jeffrey H. "Driving to the Panopticon: A Philosophical Exploration of the Risks to Privacy Posed by the Highway Technology of the Future." Dartmouth: Ashgate, 2001.

[5] Bozovic, Miran. Ed. Introduction. "An Utterly Dark Spot." New York: Verso, 1995.

[6] Kafka, Franz. The Castle. Trans. Mark Harman. New York: Schoken, 1998.

[7] Pease-Watkin, Catherine. "Bentham's Panopticon and Dumont's Panoptique." London: Bentham, 2006. 